where an effort is being made to give school courses a content suitable to African environment. But native education is still in its initial stages and the wider employment of Africans in the public services is delayed, owing to the lack of candidates fit to receive special training for their work. The most pressing need in regard to popular education in British territories appears to be better means of control and improved standards of teaching. The future of advanced education must remain in some doubt until the Government arrives at some definite policy on the position which the native is to occupy in the administrative and technical departments, particularly under a system of indirect rule. In the French possessions, education forms an essential feature in the policy of 'association'. A carefully devised system separates the elite from the mass, giving the former a training which engages their sympathy with French culture and makes them efficient auxiliaries in the work of administration. The chief characteristic of the Belgian system is its effort to improve the African's capacity for the work of developing the Congo.

In discussing the internal and external aspects of economic development, the report has much interesting material for consideration, and makes the pregnant deduction from current tendencies, that in the future the European may move away from general agriculture into commerce or various forms of non-agricultural enterprise.
On the other hand, the future economic prosperity of some of these countries probably depends more upon the general development of native economic activity than on the results of European enterprise. The African, however, cannot achieve his economic development without a material change in his present social customs.

We see before us now the most formative period of African history. Much that is done to-day will have a decisive effect on the future of the African peoples. The task of guiding the material and social development of Africa gives rise to problems which cannot be solved by the application of routine knowledge; they require a special knowledge, which can only be gained by an intensive study of the unusual conditions. This study must be pursued in the field of the social as well as the physical sciences. For this purpose assistance is required from the Imperial Government. This should take the form of a grant to be administered either by a Committee of the Privy Council or by the Economic Advisory Council. Further, the difficulty which is now felt in readily securing information about Africa should be met by the establishment of an African bureau covering social, economic, scientific and administrative problems, which will constitute both a clearing house for information, and a source of assistance to aid all those who are pursuing research or inquiry into African questions.

\title{
Czechoslovakia's Contributions to Science: A Survey and a Forecast
}

\section{By Dr. Gerald Druce}

$W^{\text {HEN the Czechoslovak state regained its }}$ independence in 1918, the people looked forward to a period of fruitful constructive effort in industry, education, culture and science. Despite a long period of subjugation, the nation could look back upon a tradition in the field of science and learning. The University of Prague, the oldest in Central Europe, was founded in 1348, and during the Middle Ages, the natural sciences flourished in Bohemia, as is shown by the number of herbals and contemporary mineralogical and alchemical works in the Czech langriage.

With the defeat, in 1620, of Frederick, the elected king of Bohemia and son-in-law of the English monarch, Bohemia not only lost its independence but also an end was put to all cultural and scientific activities for more than a century. Practically all $\mathrm{Cz}$ ech publications had then to be printed in Poland, Holland and certain German States. The University was handed over to the Jesuits, who combined it with their college, which had existed since 1556. It was re-named the Charles-Ferdinand University ; German gradually displaced Latin as the language of instruction. Science was scarcely taught, and although Adam Zalužansk'y in 1604 had insisted that botany, for example, should be considered a separate subject, what courses there were covered all the sciences. Among the few distinguished professors was Jan Bohač (Bohadsch), but, even his comprehensive "Flora, fauna et historia regni lapidei Bohemiae" remained in manuscript. When he died in 1768 , the science chair remained vacant until 1775 , when his pupil, Zauschner (who re-discovered the Gagea Bohemica described by Jan Cerny in the fifteenth 
century), gave some lectures on natural history. His successor was J. G. Mikan, a medical man who lectured mainly on chemistry.

A cultural revival first became possible towards the beginning of the nineternth century, when certain noblemen with a feeling of local patriotism became patrons of science. Thus, through the efforts of Count Ignatius Born, the Bohemian Scientific Society was founded in 1775 . This society interested itself primarily in the study of local flora, fauna and minerals, but later turned its attention also to mathematics, astronomy and physics. Count Malabaila Canal, a foreign resident in Prague, laid out a garden for the cultivation of economic plants and founded an institute for lectures in botany to be delivered by distinguished Czech botanists. These were given for more than thirty years, but ceased when Count Canal died in 1826.

Science found its strongest supporter, however, in Count Kaspar Sternberg, the centenary of whose death falls this year. He was himself a botanist and palæontologist and the author of many scientific works; but his greatest achievement was the founding of the Bohemian National Museum in 1818. To this he not only presented his own extensive collections but also be impoverished himself to purchase books, minerals and herbaria from others, especially Czech collectors whose expeditions abroad he sometimes financed. $\mathrm{He}$ also liberally supported the scientific periodical, Krok, which appeared between 1820 and 1840 under the editorship of J. S. Presl, who published in Czech much contemporary scientific work.

The National Museum was important because it developed an interest in science, though after Sternberg's death it widened its scope to become the rallying point of all Czech culture. Nevertheless, this was a period when Bohemia possessed a number of famous biologists, such as the brothers Presl, A. J. Corda and F. M. Opiz, all of whom made contributions to the advancement of botany, whilst A. Frič and J. E. Purkyně became famous zoologists. The University could not escape the effects of the national revival movement, and outstanding personalities like Purkyně lectured in Czech, despite official disapproval. Eventually, in 1882 , the University was divided into the Czech Charles University and the German (Ferdinand) University, which retained most of the buildings and possessions.

Despite difficult circumstances, the Czech pro. fessors soon began to make valuable contributions to the natural sciences. The first modern chemist was Stolba, who was followed by Brauner, but only after persistent pleas was the new Chemical Institute erected in 1903, largely on the strength of Brauner's international reputation from his work on the rare earths and atomic weights. A few other institutes, for example, for physics and botany, were eventually built, but the more specialized branches of science had to wait until the establishment of the republic before they had more than improvised accommodation.

A number of chemists, Stěrba-Böhm, Heyrovský, Tomiček and Křepelka, have followed some field of chemistry initiated by Brauner. In physics, F. Kolaček was a pioneer in electromagnetism and the physics of the ether and V. Posejpal contributed to a number of topics, including the refrac. tivity of gases at low pressure. K. V. Zenger was famous for his work on solar meteorology, and mineralogy (especially local) was developed by F. Slavík, who has frequently collaborated with British authorities. In biology, Purkyn had been followed by Sachs. Then came F. L. Celakovský, who laid the foundations of plant physiology (in which he has been ably succeeded by $B$. Němec), and upheld the view that floral members are modified leaves. In systematic botany, K. Domin has continued in the tradition of foreign expeditions, notably to Australia, India and the West Indies, whilst J. Velenovsky's work on fungi is a classic in that field.

Many notable advances have been made by Czechs other than those associated with the Charles University. The researches of Stoklasa and of Votoček and their collaborators was, for example, done at the Polytechnic, and the other universities and institutes have also contributed to scientific knowledge.

The German University, after the division of 1882 , concentrated mainly upon the study of German literature. Nevertheless, work of permanent scientific value has been carried out by Roth. mund in physical chemistry, E. F. Freundlich in astronomy, Waldschmidt-Leitz in microchemistry, F. G. Pringsheim and V. Czurda in plant physiology and M. Stark in mineralogy. The German University served the German-speaking community of Czechoslovakia and also attracted students from abroad. Now that the country has lost the territory from which its students came, its raison d'être has largely disappeared. It has been reported that the German University will continue with support from Germany, but this seems doubtful, since those professors with Nazi sympathies have left. The others include some who cannot be regarded as Aryans. Another proposal is that the University should move to Reichenberg (Liberec) or some other town in the ceded territory, but this proposal, also, has its difficulties.

Their liberation in 1918 did not blind the Czechs to their obligations towards the other nationalities within their frontiers, and adequate provision was made for them in elementary, secondary, and 
technical schools, whilst the Germans in Czechoslovakia were the only minority to possess a university of their own. Indeed, in some ways the minority was more fortunate than the Czechs, for at the German University there was one professor for every forty students, whereas at the Czech University the ratio is one to forty-eight.

Altogether, the republic possessed some twentyeight institutions of university rank. Advanced science teaching and original work is carried on at the universities, the polytechnics and at various special schools, such as that for mining at Pribram, the Brno veterinary college, and at forestry schools and institutes for glass technology. All have hitherto enjoyed generous support from the State. Moreover, a number of industrial undertakings have fostered specialized research work. Among these must be included the Radium Institutes of Prague and Jáchymov, the research laboratories of the Chemical Union, and those of the sugar industry, the leather trade, the forestry commission, the agricultural society and even much of the horticulture at Blatna is work of a scientific character.

As has been said before (see NATURE, Oct. 8, p. 637), various scientific and cultural institutions at Jáchymov (St. Joachimsthal), Usti (Aussig), Liberec (Reichenberg) and Opava (Troppau), to mention some of the more important ones, go with lost territory. These may still be utilized for local needs, but they are lost to Czechoslovak culture and science. More serious than this loss will be the curtailment of revenue without any compensating reduction of State liabilities, and it is obvious that the mutilated republic cannot continue to support its scientific and other educational institutions on the same scale as hitherto. A forty per cent 'cut' is to be made in the budget of the ministries, and it is to be feared that research and science will feel the full force of this necessity. The outlook for university staffs and the research workers is anything but reassuring. Amalgamations and the closing of minor institutions seem inevitable, and indeed this has already commenced.

The outlook for Czech scientific societies and publications is also serious. With diminished scope and reduced resources, many societies and their journals will find it difficult to continue unless they are able to secure assistance from abroad. Meanwhile, throughout the anxious weeks of uncertainty and national disaster, the university staffs, school-teachers and public officials have shown a remarkable courage, self-denial and discipline although for them, each and all, the future holds no security. A nation that has survived previous cultural and national disasters, coupled with persecution, will not lightly give up the struggle for a better future. First efforts must be directed towards economic survival. When this is vouchsafed, it will again be possible for men of science to continue in the traditions of their distinguished predecessors.

\section{Obituary Notices}

\section{Miss Clotilde von Wyss}

$\mathrm{B}$ $Y$ the death on November 7 of Miss Clotilde von Wyss, the world of education has lost an outstanding teacher of natural history, distinguished by her philosophical outlook and by her sympathetic attitude towards living things.

Clotilde von Wyss was born in Switzerland in 1871, and received the earlier part of her education at a school in Zurich, but from 1884 until 1891, she was a pupil at the North London Collegiate School. She was trained as a teacher at the Maria Grey College, Brondesbury, and after her course there gained distinction. in the Cambridge Teachers' Certificate. From 1894 until 1897, she taught at St. George's High School, Edinburgh, and during that time she was an external student at the Heriot-Watt College, coming under the influence of the distinguished naturalist, J. A. Thomson, then a lecturer in the University. Miss von Wyss valued this experience extremely highly and always spoke of the late Sir Arthur Thomson with the greatest affection and esteem. From 1897 until 1900 she taught biology at the North London Collegiate School, after which she was a lecturer at the Cambridge Training College for Secondary Teachers. In 1903, she joined the staff of the London Day Training College, and here for thirty-three years she was a successful and stimulating lecturer in natural history and hygiene and a highly valued colleague.

Miss von Wyss was a brilliant and inspiring teacher. She had a wide knowledge of natural history and an infectious enthusiasm for the educational principles which she upheld. She never lost sight of the interdependence of theory and practice, and after the free and friendly discussion of school problems that prevailed in her classes, her students went out to teach with a feeling of power and confidence. She had a delightful personality, a lightness of touch and a sense of humour which helped her in surmounting difficulties and affected even the most unpromising students. Teachers of many years standing still remember her with affection and 